The International Journal Of Engineering And Science (IJES)

|| Volume || 6 || Issue || 1 || Pages || PP 12-16 || 2017 ||

ISSN (e): $2319-1813 \operatorname{ISSN}(\mathrm{p}): 2319-1805$

THE IJES

\title{
Evaluation of the Auditors Competency in Implementing the Auditing at the Inspectorate Kendari City
}

\author{
${ }^{1}$ Tuti Dharmawati, ${ }^{2}$ Hasbudin, ${ }^{3}$ Andi Basru Wawo, ${ }^{4}$ Arifuddin Mas'ud \\ ${ }^{1234}$ Departement of Accounting, Faculty of Bussines and Economics, Halu Oleo University Kendari, Southeast \\ Sulawesi, Indonesia
}

\begin{abstract}
The results of this research indicate that the auditors competency at the Inspectorate Kendari City is adequate. This is evidenced by the spread of questionnaires that answered by the respondents under five indicator, namely the background of education, technical competence, the JFA certification and continuing education and training, the experience of the audit and skill. The fifth indicator that can increase the auditors competency. This research is aimed to evaluation of the auditors competency at Inspectorate Kendari City the implement the audit. Data collection tekhniques used in research by using questionnaire, interview and documentation. As for sample in this research are auditor and PPUPD at Inspectorate Kendari City that as many as 28 respondents. Data sources used the primary data and secondary data. The methods used data analysis is descriptive analysis.
\end{abstract}

Keywords: evaluation, competency, auditors, auditing

Date of Submission: 07 January 2017

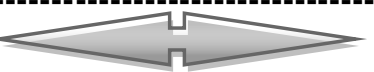

Date of Accepted: 20 January 2017

\section{INTRODUCTION}

In an effort to improve the efficient and effective implementation of the regional government, the participation of all parties is needed for the people especially of officers who will carry out the government. Providing effective governance is an urgent need, especially during the current reform. Directions approach that is focused in providing services to the community and as a policy delivery and the central government as well as implementers of government programs.

One of these units is exercised control regional inspectorate. The role and functions of the Provincial Inspectorate, District / city is generally governed by Article 4 of Regulation of the Minister of the home country, number 64 of 2007. In this article it is stated that in carrying out supervisory duties of government affairs, Provincial Inspectorate, District / City have a function, namely, (1) Planning supervision program, (2) policy formulation and monitoring facilities, (3) examination, investigation, testing and assessment of supervisory duties.

Meanwhile, to carry out its duties, the Provincial Inspectorate, District / City have the authority: (1) assist the Governor in the examination of the implementation of the Local Government assignment covering the areas of governance and development, the economy, the financial and assets, as well as specialized field; (2) Testing and assessment of the correctness of periodic reports or any time of each unit / work unit; (3) Development of functional supervision within the State Inspectorate; and (4) Implementation of evaluation and reporting of the implementation of the State Inspectorate tasks.

The Inspectorate Kendari City task of helping the mayor in the administration and implementation of the Local Government Development Control field and serves as the inspection of the Local Government, District and Sub-District. Within the scope of Local Government, the competence of Inspectorate is needed to run funsinya as pegawas to performance as well as the effectiveness of the management control system organized by the regional work units.

The results of tests carried out external auditors on Local Government Finance Report Kendari city, that financial statements of Kendari city are in accordance with Indonesian Financial Accounting Standards (SAK/ETAP/IFRS). Opinion given by the external auditor after the inspection is unqualified. Of the opinion can be seen that the performance of regional work units in Kendari city has been good. Likewise with the performance of the internal auditors of local government, especially the Inspectorate of Kendari city as to the status of the casual without exceptions will be proof that the auditor Inspectorate of Kendari city has been working professionally since there is no difference in the results of the audit of Inspectorate Kendari city to Audit Board of Republic Indonesia representatives of Southeast Sulawesi province, especially of the casual without exceptions in 2014 of Kendari city really in a position clear without notes. 


\section{LITERATURE REVIEW}

Auditing is an examination conducted by the crisis and systematically by an independent party, the financial statements prepared by management, along with the copy of records and supporting evidence, in order to be able to give an opinion on the fairness of the financial statements (Sukrisno 2012: 4). Internal audit is an objective consulting activity and confidence that is managed independently within the organization and directed by a philosophy of adding value to improve the operations of the organization. The audit helps the organization in achieving its objectives by applying a systematic and disciplined approach to evaluate and improve the effectiveness of the risk management process, the adequacy of the control and governance of the organization (Ardeno, 2012). Internal auditors are persons or entities who carry out internal audit activities. Therefore, The Internal auditor continually strive to enhance and complement each activity and the direct evaluation of any form of supervision to be able to follow the development of increasingly complex business world. The main task of an internal auditor is to evaluate and contribute to the improvement of the risk management process, of control and governance using a systematic approach, regularly and thoroughly.

Competency means the skill or ability to perform a job or profession. A competent person means a person can do his job with good quality results. In broad terms, the competence includes the mastery of knowledge and skills covers, as well as to have the attitude and behavior appropriate to carry out the job and profession. When the notion of competence include these three elements of knowledge, skills , attitude and behavior, then a competent person with the same professionalism. Competences in the narrower sense that is only associated with the knowledge and skills alone, without considering the attitudes and behavior (Principles of the code ethics IAI in Sukrisno:2014). Competency Internal auditors by the Indonesian Government Auditing Standards issued by the Internal Audit Association of the Indonesian Government and Regulation of the Minister of State for Administrative Reform, Number: PER / 05 / M.PAN / 03/2008 on Auditing Standards Government Internal Supervisory Apparatus namely educational background, technical competence, certification of functional positions auditor (JFA) and education and ongoing training, audit experience and expertise.

Research conducted by I Wayan (2011) about the effect of competence to audit quality. The analysis tool used is simple regression analysis with the results showed that the competencies measured by the knowledge and experience positive effect on audit quality as measured by compliance with audit standards and the quality of reporting on BPKP Southeast Sulawesi. The equation that research in this study is the variable competence. Josua and Lidya (2016) regarding quality evaluation in the Government Internal Supervisory Apparatus Regional Financial Supervision Studies in The Government Southeast Minahasa District. The analysis tool used is a qualitative descriptive analysis in technique comparative analysis between indicators that have been determined by the answers given by the actual conditions in the field. Results from these studies are Competency of labor inspectors in the Inspectorate Southeast Minahasa District less and does not support audit activities and supporting infrastructure and supporting owned APIP not support the audit and review of financial statements.

\section{Framework}

The Inspectorate Kendari City is one of the government agencies engaged in surveillance and also has the function of inspection. Auditors in the Inspectorate Kendari City in demand to work in a professional manner in order to support the effectiveness of internal control. Auditor competency criteria by the Indonesian Government Internal Audit Standards issued by the Internal Audit Association of the Indonesian Government and Regulation of the Minister of State for Administrative Reform, Number: PER/05/M.PAN/03/2008. Based on the description above framework, then made a schematic framework for analyzing the above problems by using descriptive analysis in Figure 1:

\section{Auditors Competency: \\ 1. Background of Education \\ 2. Technical Competence \\ 3. JFA Certificationand Education and Sustainable training \\ 4. Audit Experience \\ 5. Expertise}

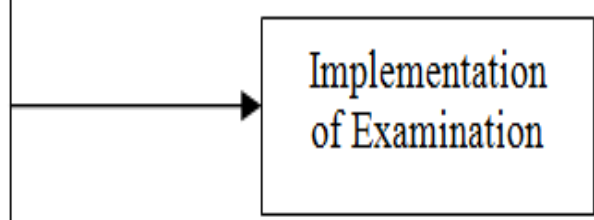

Figure 1. Framework 


\section{RESEARCH METHODS}

The object of this research is the auditors competency in the implementing the auditing at the Inspectorate Kendari City.

The population in this study were all auditors with functional and PPUPD located in the Inspectorate Kendari City totaling 28 people. The sampling method used census method.

Analysis of the data used is descriptive analysis using a measurement that Guttman Scale, where the scale of measurements obtained with this type of unequivocal answer "Yes or No". The criteria at every level adjusted with questions. Each criterion is given a score according to the actual conditions that occur at the level of the organization with which to answer "Yes" was given a score of 1 and for "No" was given a score of 0 . Nasution,S (2003: 61) says that to know the percentage of responses from questionnaires distributed, using a formula that is the percentage of the number of "Yes" divided by the number of responses to questionnaires multiplied by 100. In accordance with the formula, the competence of auditors to perform the examination can be seen from the percentage the results of the analysis are (a) $<59 \%$ is inadequate, (b) $60 \%-69 \%$ is inadequate, (c) $70 \%-79 \%$ is said adequate, (d) $80 \%-89 \%$ is adequate, and (d ) $90 \%-100 \%$ is very adequate.

\section{RESULTS AND DISCUSSIONS}

\section{Results}

The results of the evaluation competency auditor by Standard Internal Indonesian government viewed from various perspectives such as educational background, technical competence, JFA certification and continuing education, audit experience, and expertise. Based on interviews and answers from respondents and the results of studies conducted to evaluate the auditors competency at Inspectorate Kendari City:

Table 1 Recapitulation Respondents answer of Auditor Competency

\begin{tabular}{|l|l|l|l|}
\hline Indicators & $\begin{array}{l}\text { Number of Answers } \\
\text { "Yes" }\end{array}$ & $\begin{array}{l}\text { Percentage } \\
(\boldsymbol{\%})\end{array}$ & Criteria \\
\hline Auditors Competency Qualifications: & & 83.33 & Adequate \\
1. Background of Education & 55 & 86.36 & Adequate \\
2. Technical Competence & 57 & 97.73 & Adequate \\
3. JFA Certification and Sustainable & 43 & 77.27 & Adequate \\
$\quad$ Education and Training & 44 & 93.18 & Adequate \\
4. Audit Experience & 41 & $\mathbf{8 7 . 1 2}$ & Adequate \\
5. expertise & $\mathbf{2 3 0}$ & & \\
\hline
\end{tabular}

Source: The Primary Data Processed, 2016

\section{a. Educational background}

The results of respondents answer amounted to $83 \%$, means that the educational background of the auditor's at Inspectorate Kendari City is adequate. Where the first question items related to the level of formal education possessed adequate auditor shows the number of $100 \%$, which means very adequate. The second question items related to technical training followed by adequate auditor shows the number of $100 \%$, which means very adequate. The third question items related to barriers to auditors who do not have the educational background of accounting in carrying out the inspection process is not adequate.

\section{b. Technical competence}

The results of respondents answer of $86 \%$, means that the technical competence of auditors Inspectorate Kendari City is adequate. The first question related items auditor must have must have knowledge in the field of inspection with the percentage of $91 \%$ is very adequate. Item the second question regarding the ability to be owned by the auditors in carrying out the examination, with the percentage of $86 \%$ is adequate. Ability needs to have an auditor that is professional, integrity, independent, competent and effectively communicate with the client. The third question items related to other knowledge that is necessary to support the auditor possessed the competence he had with the percentage of respondents $82 \%$ is adequate. Knowledge of other than the auditor's such as knowledge in the field of law, management, engineering and others.

\section{c. Auditors functional certification and sustainable education and training}

Based on Table 1, above, the yield of the respondents of $98 \%$ means that the certification of functional positions auditor as well as continuing education and training inspectorate auditor Kendari very adequate. Item the first question about the auditor should follow functional certification auditor to the percentage of $100 \%$ is very adequate. Item the second question about the auditor needs to follow the education and continuous training for the inspection process with the percentage of respondents, $95 \%$ is very inadequate, means auditors often on continuing education for its accession process as well as the promotion of sustainable training to increase the knowledge and expertise of auditors in carrying out the examination. 


\section{d. Audit experience}

Based on Table 1, above, the yield of the respondents of $77 \%$ means that the auditor auditing experience Inspectorate Kendari City inadequate. Item first question about an auditor who has had experience of the audit will support the competence of auditors. Based on interviews and respondents auditor's experience is sufficient to support the auditors' competence. Item the second question related to the length of a person becomes auditor will add to the experience of auditors are adequate means of interviews and respondents that the auditors have conducted the audit assignment for 5-7 who have worked for more than 10 years already checks for 5-10 agency means with the number of audits that auditors would be easy to detect errors in the financial client.

\section{e. Expertise}

Based on Table 1, above, the yield of the respondents of $93 \%$ means that the auditor audit experience Inspectorate of Kendari very adequate. Item question the expertise of auditors in the examination process. The percentage of $100 \%$ is very adequate. The membership consists of proficiency in computer use, expertise in conducting interviews for inspection process. Item the second question about the skills possessed auditor in performing audit procedures. Answer "Yes" to the percentage of $86 \%$ is adequate, meaning that the auditor was able to complete the examination in accordance with the audit procedures that have been made previously set.

\section{Discussion}

Based on the results of the evaluation has been done then the auditors competence at Inspectorate Kendari City is adequate based on the Government Internal Audit Standards.

\section{a) Background Education}

Based on the background SAIP owned Inspectorate Kendari city auditor is adequate. Auditor Inspectorate of Kendari own formal education degree (S1) and postgraduate (S2) with a background in accounting education, management, law, engineering, and others, as well as follow technical training before conducting examinations such as training the examination of financial statements, training the basics of auditing, training and SAIP LKPD review, and training on taxation.

\section{b) Technical Competence}

A second indicator is the technical competence where common knowledge that must be possessed by an auditor relating to the inspection process so that checks are carried out went well. Auditor Inspectorate Kendari City has had a general knowledge such as accounting, auditing, gained from formal education and training which have been followed.

\section{c) Certification of Functional Auditor (JFA) and sustainable education and training}

A third indicator that auditor functional certification and continuing education and training. This may imply that the auditor Inspectorate Kendari City follow JFA certification and continuing education for raising the rank and ongoing training to increase knowledge and skills of auditors.

\section{d) Auditing experience}

Based on interviews and answers to questionnaires from respondents regarding the fourth indicator is that the experience of auditing the auditor Inspekrorat Kendari sufficient. The experience in question here is the experience of auditors in conducting the examination of financial statements in terms of both the length of time, or the number of audits that have been done. Experience of auditors in carrying out the examination of 5-10 years with a number of agencies were examined with a position as supervisory auditor, auditor young experts, and the first auditor.

\section{e) Expertise}

Based on the research that has been done, the percentage level of expertise of auditors in Inspectorate of Kendari sufficient means to carry out the functions and duties of auditors have adequate expertise. It can be seen from the education, experience and knowledge of internal auditors Inspectorate Kendari. Auditors have a very inadequate knowledge about the audit, the auditor Inspectorate improve his skills Kendari constantly getting and special training in the field of auditing. Inspectorate Kendari City and auditors have the skills in the audit reporting process and have the ability to present the results of the audit report. 


\section{CONCLUSIONS AND SUGGESTIONS}

Based on the results of research and discussion that has been done, the authors concluded that the auditors competence at Inspectorate Kendari City is adequate. It can be seen in the percentage of responses to questionnaires conducted on 22 respondents from each of the indicators that support the functional competence of auditors Inspectorate of Kendari with a percentage of $87 \%$.

Some of the suggestions and recommendations made by the authors based on the results of this study are as follows: (1) The internal audit conducted auditors, should not tell the object to be examined that will be held inspection, (2) Inspectorate Kendari City should be increased attention to the educational background, technical competence, JFA certification and continuing education and training, audit experience and expertise to improve the competence of its auditors in order to carry out supervisory duties properly, (3) The study was only done at the Inspectorate Kendari City so as to obtain general conclusions need to do more extensive research, and (4) for further research is recommended to add a variable to find the test results and new knowledge.

\section{REFERENCES}

[1]. Agoes, Sukrisno dan I Cenik Ardana. 2014. Etika Bisnis dan Profesi Tantangan Membangun Manusia Seutuhnya. Edisi revisi. Jakarta: Salemba Empat.

[2]. Agoes, Sukrisno. 2012. Auditing. Edisi 4. Buku 1. Jakarta: Salemba Empat.

[3]. Arenz, Alvin A et.al. 2012. Auditing and Assurance Services: an Integrated Approach. Edition 14. Prentice Hall International.

[4]. Asosiasi Auditor Intern Pemerintah Indonesia. 2014. Standar Audit Intern Pemerintah. Jakarta: BPKP www.bpkp.go.id Mei 2016

[5]. IAI. 2015. Standar Profesional Akuntan Publik. Jakarta: Salemba Empat.

[6]. I Wayan. 2011. Pengaruh Kompetensi terhadap Kualitas Audit. Program Studi Akuntansi Fakultas Ekonomi dan Bisnis, Universitas Halu Oleo.Kendari

[7]. Josua, dan Lidya. Evaluasi Kualitas Aparat Pengawas Intern Pemerintah Dalam Pengawasan Keuangan Daerah. Jurnal Akuntannsi. www.google.com Mei 2016

[8]. Kumaat, G Valery. 2011. Internal Audit. Jakarta: Penerbit Erlangga

[9]. Kurniawan, Ardeno. 2012. Audit Internal Nilai Tambah Bagi Organisasi. Penerbit Fakultas Ekonomika dan Bisnis UGM, Yogyakarta.

[10]. Kuncoro, Mudrajad., 2007. Metode Kuantitatif Teori dan Aplikasi Untuk Bisnis dan Ekonomi. Penerbit Unit Penerbit dan Percetakan (UPP) STIM YKPN. Yogyakarta.

[11]. Kode Etik dan Standar audit. 2008. Pusdiklat Pengawasan BPKP. www.bpkp.go.id April 2016

[12]. Mulyadi. 2002. Auditing Edisi Enam. Jakarta: Salemba Empat.

[13]. Peraturan Menteri Negara Pendayagunaan Aparatur Negara PER/05/M.PAN/03/2008. Standar Audit Aparat Pengawasan Intern Pemerintah. Jakarta. www.bpkp.go.id April 2016

[14]. Peraturan Kepala Badan Pengawasan Keuangan dan Pembangunan Nomor: PER-211/K/JF/2010. Standar Kompetensi Auditor. Jakarta. www.bpkp.go.id April 2016

[15]. Peraturan Menteri Dalam Negeri No. 64 Tahun 2007. Peran dan Fungsi Inspektorat Provinsi, Kabupaten/Kota. Jakarta: www.google.com April 2016

[16]. S.Nasution. 2003 Metode Research (Penelitian Ilmiah). Jakarta: Bumi Aksara

[17]. Sugiyono. 2012. Statistika Untuk Penelitian. Bandung: Alfabeta. 